\title{
The Lexicographical Handling of Grammatical Equivalence: The Case of Afrikaans and Zulu
}

\author{
Ernst F. Kotzé, University of Zululand
}

\begin{abstract}
Lexicographers compiling translating dictionaries are not exdusively concerned with semantic equivalence when selecting translating equivalents for lemmata, but often include also grammatical information in illustrative examples when the lexical item to be translated does not have an exact grammatical counterpart in the target language. This is especially so in the case of typologically divergent languages, of which Afrikaans and Zulu are representative examples in the South African context. In the application of translation theory to lexicographic practice, it seems sensible to decide in favour of a descriptive approach (Toury 1980), which, in contrast to the prescriptive approach, does not assume an ideal relation between source text and target text, but in fact examines the relation between the two texts (which correlates in the case of a translating dictionary respectively with lemma and translating equivalent) in an empirical way. In this article, the problem of grammatical disparity between lemma and translating equivalent in a learners' dictionary involving the above-mentioned languages is considered. Not only disparity relating to syntactic categories, but also the morphological status of lemmata (as words, and as sub- and multilexical items) are covered in the investigation of the data. As a consequence of the insights thus gained into the systematic nature of this asymmetric relation, suggestions are made to utilise the format of the microstructure as a means to convey grammatical facts of the target language to the learner.
\end{abstract}

Keywords: AFRIKAANS, GRAMMATICAL EQUIVALENCE, LEARNERS' DICTIONARIES, LEXICOGRAPHY, MACROSTRUCTURE, MICROSTRUCTURE, MORPHOLOGY, SYNTAX, TRANSLATING DICTIONARIES, TRANSLATION THEORY, TRILINGUAL DICTIONARIES, ZULU

Opsomming: Die leksikografiese hantering van grammatikale ekwivalensie - die geval van Afrikaans en Zoeloe. Leksikograwe wat vertalende woordeboeke saamstel is nie uitsluitlik gemoeid met semantiese ekwivalensie wanneer hulle vertaalekwivalente vir lemmas selekteer nie, maar sluit dikwels ook implisiete grammatiese inligting in by wyse van voorbeeldmateriaal wanneer die leksikale item wat vertaal moet word, nie 'n presiese grammatiese teenhanger in die teikentaal het nie. Dit is veral so in die geval van tipologies uiteenlopende tale, waarvan Afrikaans en Zoeloe as voorbeelde in die Suid-Afrikaanse tale-opset dien. By die toepassing van die vertaalteorie op die leksikografiese praktyk lyk dit sinvol om ten gunste van 'n deskriptiewe benadering (Toury 1980) te kies, wat, anders as die preskriptiewe benadering, nie in ideale verhouding tussen bronteks en doelteks veronderstel nie, maar juis die verhouding tussen die twee tekste (wat in die geval van 'n vertalende woordeboek korreleer met 
lemma en vertaalekwivalent onderskeidelik) empiries ondersoek. In hierdie artikel word die probleem van grammatikale ongelyksoortigheid tussen lemma en vertaalekwivalent in ' $n$ aanleerderswoordeboek wat die bogenoemde tale betrek, dan onder die loep geneem. Nie alleen ongelyksoortigheid met betrekking tot sintaktiese kategorieë nie, maar ook die morfologiese status van lemmas (as woorde, en sub- en multileksikale items) kom in die data-ondersoek aan bod. Die insigte oor die sistematiese aard van hierdie asimmetriese verhouding wat sodoende verkry word, vind neerslag in voorstelle om die formaat van die mikrostruktuur in te span as middel om grammatikale feite van die teikentaal by die aanleerder tuis te bring.

Sleutelwoorde: AANLEERDERSWOORDEBOEKE, AFRIKAANS, DRIETALIGE WOORDEBOEKE, GRAMMATIKALE EKWIVALENSIE, LEKSIKOGRAFIE, MAKROSTRUKTUUR, MIKROSTRUKTUUR, MORFOLOGIE, SINTAKSIS, VERTAALTEORIE, VERTALENDE WOORDEBOEKE, ZOELOE

\section{INTRODUCTION}

If the information contained in translating dictionaries is compared to that in their declarative counterparts, it is clear that translating dictionaries possess a theoretical dimension which, at the most, plays a minor role in declarative dictionaries. In addition to the fact that both contain the normal orthographical, phonological, semantic, grammatical and contextual entries which form part of the microstructure of an article, the theoretical framework within which the lexicographer works, in the case of translating dictionaries, plays an important role in selecting a target language equivalent. This choice is to a large extent determined by the lexicographer's approach to the relation between source text and target text.

In translation theory the traditional distinction between a prescriptive and a descriptive approach is made by Toury $(1980)$ and further discussed by Büttner (1991). The prescriptive approach attempts to answer the question whether a translated text is equivalent to its source text. The descriptive approach, on the other hand, rather investigates the nature of the equivalence if text $A$ is regarded as a translation of text $B$. In terms of the prescriptive approach, the point of departure for equivalence is (a) the source text and (b) the translation process, or put differently, the "translatability" of a text and the translation possibilities at the disposal of the translator. This presupposes an abstract or ideal relation between the source text and the target text. Translating equivalence is thus a prerequisite for establishing any relation between the two texts. The descriptive translation theory is aimed at the target text, however, and the relation between the two texts is analysed and described as an empirical phenomenon.

It should be clear that the prescriptive approach must lead to a speculative theory, because it accepts (and expects) both semantic and grammatical equivalence. The nature of the equivalence RELATION between source text and 
target text is not considered. It is, of course, a fact that in genealogically related languages a fairly consistent correlation between semantic and grammatical equivalence is normally displayed. (A transitive verb in French or German is usually translated by means of a semantically equivalent transitive verb of the same subcategory in, say, English.) In the case of genealogically unrelated or typologically divergent languages, however, this correlation is often conspicuously absent and it is therefore important to explain systematic differences between the two languages on the grammatical level. For this reason the descriptive approach is the proper point of departure to investigate equivalence relations and to raise, in the case of a translating dictionary, the problem of grammatical equivalence.

\section{THE NATURE OF THE PROBLEM}

Grammatical dissimilarity between lemma and target language equivalent in a translating dictionary is not so much a problem when the lemma component in the macrostructure of the dictionary represents the learner's target language, in other words, when the target text (in the context of translation) is her/his L1. The syntactic and morphological entries of the article normally sufficiently elucidate the usage of such a target language lemma, especially if contextual guidance is given in addition by means of exemplary material. A problem does arise, however, when the lemma is in the $\underline{L l}$ and the target language equivalent, as a result of typological differences between the languages concerned, is not grammatically equivalent to it. Because the microstructure of translating dictionaries usually does not provide for explicit grammatical information regarding the target language equivalent, and the latter does not always represent a monolexical grammatical category, the learner receives no formal paradigmatic guidance elucidating further possible applications of the translating equivalent. The value to the learner of such an article is thus restricted and only determined eventually by the measure in which the usage of the translating equivalent becomes clear within the given context. It is at this point that the function of a learners' dictionary, which should be aimed at providing the user with the necessary lexis and structure in a learner-friendly fashion and by means of contextual guidance, is highlighted.

The problem is complicated further in that inflected, or, more generally speaking, morphologically adapted forms of the translating equivalent are used in the illustrative examples, and often deviate from the basic form to such an extent that the learner who has not yet acquired the necessary morphonological skill, would not recognise it as the same lexical item. In an agglutinating language like Zulu the use of such a translating equivalent in its syntactic and morphological contexts can often lead to a form which first has to be disentangled before the learner can relate it to the lemma.

In this article I aim to focus on the problem of grammatical equivalence on 
the basis of examples from a recently published learners' dictionary ${ }^{1}$ and to regard this aspect of lexicographic practice against the background of linguistic understanding of the nature of the lexicon of the two languages concerned. The Afrikaans/Zoeloe-woordeboek met Engelse vertalings (or AZE) is the first volume of a trilingual dictionary, broadly speaking, or more specifically, a bilingual translating dictionary with a third language component which has a crossreferential function. Since a large number of illustrative examples is used in this dictionary to exemplify contextual equivalence between the lemma and translating equivalent on the semantic level, it becomes possible to investigate also the grammatical equivalence relations, something which could not have been indicated in the case of mere word translations.

\section{DATA ANALYSIS}

Although it is true that the target language form in a translating dictionary does not represent the meaning of the source language form as such (Gouws 1989:66), semantic equivalence does apply as primary criterion when two contextualised expressions containing respectively the source and target language forms are juxtaposed in the dictionary article concerned. The resultant secondary position of grammatical equivalence and the paucity of grammatical information about the target language equivalent on the whole force the user to rely in her/his deductions about the grammatical relation between the lemma and the translating equivalent either on explanatory comments in the introductory section of the dictionary, or on the illustrative examples in the relevant article. Branford describes the traditional approach to this relation as follows (1991:37):

Dictionaries, one might argue, describe grammatical structure only incidentally: their main business is with word-meanings.

He does not agree with the expressed sentiment, however, and proceeds (1991:38):

But it is a mistake to divorce sign from system, or lexis from grammar. ... The copious "examples" were a major strength of Johnson's Dictionary, making it, like Oxford English Dictionary, a mine of grammatical information, though in both texts much of this has to be gleaned from the illustrative quotations and is not spelled out explicitly.

The proclivity for semantic equivalence is also evident in the Afrikaans lexicographical tradition, and the grammatical relation between source text and 
target text is rarely described, if at all.

As mentioned above, the problem becomes more serious with an increasing extent of language typology difference between the source language and target language (Afrikaans and Zulu in the relevant example), and then especially when equivalent lexical contents are grammatically represented in a consistently different way. The predilection for semantic equivalence in translating dictionaries results in a total lack of attention to this incongruence.

On the syntactic level categorical differences can occur. For instance, a verbal category such as the copula, which has a relatively high frequency in Afrikaans, is not at all productive as a main verb in Zulu. The way in which the copula operates in Afrikaans, makes it possible, inter alia, for adjectives to form part of the predicate, in addition to their attributive and adjunctive functions. The attributive/predicative distinction in respect of Afrikaans adjectives correlates in Zulu with two other categories, viz. relative as against verb (which could be transitive or intransitive). This is also the reason why and the way in which translating equivalents of lemmas such as the following are illustrated separately (each article is followed by a morpheme translation of the Zulu items occurring in it):

(1) fantasties b.nw. =mangalisayo (fantastic) 1. dis 'n fantastiese aanbod ngumnikelo omangalisayo (it is a fantastic offer) 2. dis f. kuyamangalisa (it is fantastic)
(a) =mangalisa yo
be fantastic ASP2
(b) ngu mnikelo o

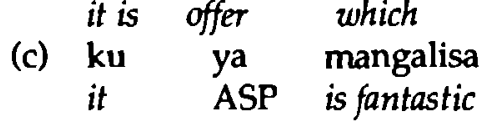
mangalisa yo
is fantastic ASP

(2) glad ( de) b.nw. =shelelayo ... 1. sy het 'n gladde tong unolimi olushelelayo (she is smooth-tongued) 2. die pad is g. vandag umgwaqo uyashelela namuhla (the road is slippery today)
(a) =shelela yo
be slippery ASP
(b) $\mathbf{u}$ no limi olu shelela yo
she has tongue which is slippery ASP
$\begin{array}{lllll}\text { (c) umgwaqo } & \mathrm{u} & \text { ya } & \text { shelela } & \text { namuhla } \\ \text { the road } & \text { it } & \text { ASP } & \text { is slippery } & \text { today) }\end{array}$ 
(3) mank b.nw. =qhugayo (limping) 1. 'n m. man indoda eqhugayo (a limping man) 2. hy is (loop) $\mathrm{m}$. uyaqhuga (he is limping)
(a) =qhuga yo
(b) indoda e qhuga yo
$\begin{array}{lll}\text { (c) } & \text { ya } & \text { qhuga } \\ \text { he } & \text { ASP } & \text { limpS }\end{array}$

(4) broeis b.nw. =fukamelayo (broody) 1 . 'n b. hen isikhukhukazi esifukamelayo (a broody hen) 2. sy is baie b. oor haar kinders ubafukamele abantabakhe (she is very possessive about her children)
(a) =fukamela yo hatch ASP
(b) isi khukhukazi esi fukamela yo

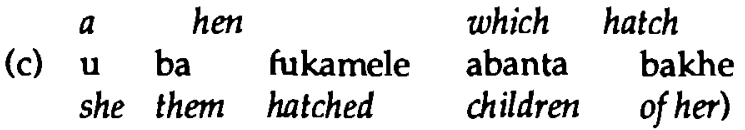

In these cases the translating equivalent of the Afrikaans lemma is consistently a relative which is based on a verb stem. ${ }^{3}$ The first example shows in every case how the relative is used in a syntactically comparable way, and hence in the same position as the adjective in Afrikaans, while the second example illustrates the use of the lemma as predicative or adjunct. In this case the syntactic difference is of such a degree that the predicate in Afrikaans has to be translated in toto by means of an intransitive (and in the last example a transitive) verb construction in Zulu. Consequently, the functionally differentiated use of adjectives in Afrikaans (e.g. attributively or predicatively) on the one hand, and the semantically more encompassing lexical item which Zulu requires as a translation of the predicate on the other, lead to a situation where a one-to-one morpheme translation based on the lemma cannot be applied consistently.

Syntactic disparity between lemma and translating equivalent in respect of Afrikaans and Zulu is apparent in other ways as well. Because grammatical functions which in Afrikaans (or English) are expressed by means of a syntactic construction, are often represented in Zulu (as an agglutinating language) by means of a morphological construction, it often happens that Afrikaans prepositional phrases are translated by a locative form of the noun in Zulu, as in the following cases: 
(5) hart ( -e) s.nw. inhliziyo (heart) 1. dit het sy h. gebreek kumephule inhliziyo (it broke his heart) 2. hy sê wat in sy h. is usho okusenhliziyweni yakhe (he speaks his mind (heart))

(a) $\mathrm{ku} \quad \mathrm{m}$ ephule inhliziyo

(b) $\mathrm{u}$ sho oku senhliziyweni yakhe
he says which is in the heart of him

(6) kus ( te) s.nw. ugu (coast); ons dorp is aan die k. geleë idolobha lakithi lakhiwe ogwini (our village is situated on the coast)
(a) idolobha
the town
lakithi
lakhiwe
ogwini
of at us is situated
on coast

(7) pad (paaie) s.nw. umgwaqo (road) 1. dis 'n slegte p. ngumgwaqo omubi (it is a bad road) 2. die motor het van die p. geloop imoto iphumile emgwaqweni (the car went off the road)
(a) ngu
mgwaqo o
mubi
it is a road
which is bad
(b) imoto i
phumile
came out
emgwaqweni
the car it
from the road

In addition to the identifiable word translation, which is repeated without notable change in respect of both hart and pad, the translating equivalents of all three lemmas, if the latter form part of a multilexical construction in Afrikaans, are expanded morphologically and amended phonologically in a single orthographical construction, as in hart (illustrative example 2). The morpheme-by-morpheme back translation in English of "okusenhliziyweni" above, as well as that of "ogwini", serves to illustrate this phenomenon.

A comparable syntactic-morphological parallelism exists in respect of passive constructions, where the Afrikaans lemma can be used practically unchanged in illustrative examples, while the verb in Zulu undergoes a morphological (by means of infixing) and sometimes even a phonological change (as a result of palatalisation). Apart from the passivation morpheme, concords and suffixes (indicating transitivity, tense or subjunctivity in the verb) are added to the stem in various combinations, so that the end result often takes the form of an embedded and even fragmented representation of the word translation. 
(8) dril ww. viva (drill) 1. die soldate word gedril amasosha ayaviviswa (the soldiers are being drilled)
(a) amasosha
a
ya viviswa
the soldiers
they
ASP are drilled

(9) invorder (ingevorder) ww. qoqa (collect); die belastings moet ingevorder word izintela kufanele iqoqwe (the taxes have to be collected)
(a) izintela ku fanele i qoqwe the tax it is necessary it be collected (SUBJ4)

(10) vra ww. cela (ask); ek is gevra om te kom ngicelwe ukuba ngize (I have been asked to come)
(a) ngi
celwe
was asked
ukuba ngi ze that I come (SUBJ)

(11) vrylaat (vrygelaat) ww. khulula (release); die gevangene is vrygelaat isibosh wa sikhululiwe (the prisoner has been released)
(a) isiboshwa
si khululiwe the prisoner
he was released

(12) inspan (ingespan) ww. bophela (harness, inspan); die perde moet ingespan word amahhashi kufanele aboshelwe (the horses must be harnessed)
(a) amahhashi ku fanele
the horses it is necess
a boshelwe
they be harnessed (SUBJ)

Although it could be argued that the morphonological rules yielding these forms constitute part of Zulu grammar and cannot therefore be offered as unique information in a dictionary, the value of a learners' dictionary lies, amongst other things, precisely in the fact that it supplements the structural descriptions and fulfils a didactic function through the choice of exemplary material. Branford (1991:42) refers to a comment by Chomsky in this regard: 
The structure-dependence of language creates the need for "structural descriptions" (Chomsky 1965) in which the disciplines of syntactician and lexicographer should converge. A major challenge to the lexicographer is that of creating "structural descriptions" that adequately reflect the valency, or patterning potential, of words or classes of words. This involves the choice of category labels as well as more extended description and exemplification.

In heeding this advice we will already have arrived at part of the solution to the problem. "Extended description and exemplification" would certainly enhance the value of such an article. However, an important factor which has to be taken note of here and which should form the basis of the utilisation of exemplary material in order to fulfil the didactic function mentioned above, is the systematic nature of the relation between source text and target text. The microstructure of an article in which the same set of grammatical relations between lemma and translating equivalents is possible, time and again can be conventionalised by also illustrating this set according to a fixed pattern and in the same sequence by means of the exemplary material. The user should in any event receive guidance in the introductory section concerning the sequencing principles according to which grammatical information is offered implicitly. In this way a link is established, albeit in an indirect way, between sign and system, between lexis and grammar, and both the semantic and grammatical relation between source text and target text are revealed.

Other examples of an asymmetrical semantic-grammatical relation include one-word derivations in Afrikaans (such as burgerskap 'citizenship' and aankoms 'arrival') correlating with an infinitive construction (mono- or multilexical) in Zulu (respectively ukuba yisikhamuzi 'to be a citizen' and ukufika 'to arrive') and a contrast between two different verbs in Afrikaans covered by a present/perfect dichotomy of the same verb in Zulu (e.g. "aantrek" 'dress' gqoka and "aanhê" 'wear' - gqoke). Also sublexical items in Zulu such as na= can be translated by means of various polysemous equivalents in Afrikaans, each representing a quite different syntactic category, namely en (conjunction), met (preposition) and het (main verb). Compare the following examples:

(13) Izikhukhukazi (the hens

namaqanda - Die henne en die eiers and the eggs)

(14) Khuluma nami - Praat met ('with') my (speak to me)

(15) Asinamali - Ons het nie geld nie (not we have money) 
Seen from the point of view of translation, with Afrikaans as lemma component, the variation in these cases occurs not in the target text, but in the source text. The result is that the structuring of such an article has to take place in the reverse translation component of the dictionary, and that the user's attention has to be drawn by means of a cross reference to the lemma concerned in that component.

From this analysis a further deduction can be made for the lexicographer, namely that the full spectrum, structurally speaking, of lexical items in Afrikaans should be covered in the macrostructure. This follows from the fact that multilexical items in Afrikaans (or English, for that matter) can often be translated by a single word in Zulu, and that Zulu bound morphemes, or sublexical items, then, have to be accepted as translating equivalents of Afrikaans words. Conversely, certain lemmas containing sublexical items in Afrikaans (such as -skap in burgerskap 'citizenship') can only be translated by means of a multilexical construction in Zulu. A word-oriented lexicography as is traditionally practised in Afrikaans cannot do justice to the grammatical variety regarding the form of lexical items in a language such as Zulu.

\section{CONCLUSION}

An analysis of those articles in AZE in which the contextual application of the translating equivalents are illustrated, reveals that the selection of illustrative examples cannot take place at random, because the analytic demands thus made on the user/learner are too high. The incidence of grammatical dissimilarity between lemma and translating equivalent on the one hand and the varying degree of morphological complexity (in different case contexts) of the translating equivalent on the other, can be an impediment to the user/learner's progress in acquiring a working knowledge of the target language in that the systematic character of the relation between lemma and translating equivalent is concealed. Such problems can largely be overcome in a translating dictionary by means of a generous supply of systematic (i.e. consciously structured), contextual exemplary material which illustrates not only morphological or word equivalents, but also the variety of syntactic equivalents occurring in typologically dissimilar languages.

\section{REFERENCES}

Branford, W. 1991. Some Dictionary Descriptions of Grammatical Structure. Harteveld, P. (Ed.). 1991: 37-42.

Büttner, C. 1991. Die vertaling van Lutherse gesange oan Duits na Afrikaans: Ekwioalensievereistes versus de facto-ekwioalensieverhoudings. Unpublished M.A. dissertation. University of the Witwatersrand. 
Gouws, R.H. 1989. Leksikografie. Pretoria: Academica.

Harteveld, P. (Ed.). 1991. Lexikos. AFRJLEX series 1: 1991. Stellenbosch: Buro van die WAT.

Kotzé, E.F. and V.P. Wela. 1991. Afrikans/Zoeloe-woordeboek met Engelse zertalings. Cape Town:

Tafelberg.

Nida, E. and R. Taber. 1974. The Theory and Practice of Translation. Leiden: E.J. Brill.

Toury, G. 1980. In Search of a Theory of Translation. Tel Aviv: Porter Institute. 